\title{
The scorpion collections (Arachnida, Scorpiones) held in the Museo Regionale di Scienze Naturali of Turin (Italy)
}

\author{
Alberto Chiarle, František Kovařík, Lisa Levi \& Elena Gavetti
}

doi: $10.5431 /$ aramit4307 Abstract: Data and considerations about the history and contents of the scorpion collection housed in the Museo Regionale di Scienze Naturali of Turin (MRSN) are reported. Information on type material and important historical specimens are provided, as well as biographical notes about the major zoologists of the museum.

Key words: Borelli, MZUT, MRSN, scorpiology, Turin collection history

In 1978 the public administration of the Regione Piemonte founded the 'Museo Regionale di Scienze Naturali' (MRSN) in Turin. Since 1980, the zoological treasures kept by the Zoological Museum of the Turin University (MZUT) have been entrusted to the MRSN. The MZUT is one of the oldest and most important Italian university museums. It was founded in 1805, during the French occupation, merging the collections of the former Royal museum of natural history and of the 'Reale Accademia delle Scienze di Torino'. Since the middle of the 19th century the museum began to acquire important and rare material from all over the world. Long and difficult expeditions were organized by the museum as well as by private researchers. During the 20th century the collections were enriched by the activities of the museum's research staff, by exchanges and gifts from other specialists and from travellers. In the first decades of the 20th century the museum's zoological research started to shift its focus towards histology and genetics, and the collections lost their primary role.

In 1936 the MZUT was moved into the 'Ospedale Maggiore di San Giovanni Battista'. Here work began to rearrange the large amount of material; then in a poor state of conservation, due to the partial lack of conserving fluid and the fading (or loss) of several labels. Interesting material and documents were lost or irreparably damaged (TORTONESE 1957). Between 1950 and 1967, notwithstanding their importance,

\footnotetext{
Alberto CHIARLE, Lisa LEVI, Elena GAVETTI, Museo Regionale di Scienze Naturali di Torino, Via Giolitti 36, 10134, Torino, Italy. E-Mail:alb.chiarle@gmail.com, lisa.levi@fastwebnet.it, elena. gavetti@regione.piemonte.it

František KOVAŘíK, P.O. Box 27, CZ-145 01, Praha 45, Michle, Czech Republic.E.Mail:frantisek.kovarik@pre.cz
}

submitted: 15.12.2011; accepted: 15.3.2012; online early: 8.6.2012 the museum collections were neglected. Specimens in ethanol suffered and exchanges, loans and systematic studies on specimens were interrupted. In 1968, under Professor Umberto Parenti's guidance and thanks to the curators, the MZUT was reorganized.

Since 1980 a large number of transfers have taken place involving all the collections.

The scorpion collection held in the Turin museum is quite large and historically important. The collection dates back to the second half of the 19th century and reflects the global perspective of the institution and the contribution of many eminent zoologists. In this first attempt we review the scorpion collections and illustrate the present situation of this interesting material - neglected for far too long - which is still needed by specialists for describing new species from all over the world.

\section{Material and Methods}

We used three different sources to review the scorpion collections, assess their scientific value and the activities within these collections over the years.

\section{Publications}

Much of the historical material was published in expedition reports or in scientific journals, mainly in the Museum review, 'Bollettino dei Musei di Zoologia e di Anatomia Comparata della Regia Università di Torino', but also in renowned Italian and international publications.

\section{The historical catalogues}

Two kinds of catalogues are present in the museum: the older handwritten catalogues which are, however, partially incomplete, and a recent one, typewritten and then mimeographed. The old loan forms and 
significant correspondence between specialists and curators proved to be very useful in verifying the collection data.

In the period 1975-1978 these catalogues, 'Cataloghi del Museo e Istituto di Zoologia sistematica dell'Università di Torino', were drawn up for most zoological groups and were sent to the most important museums and universities all over the world. In this way the exceptional heritage of the museum became available again to the international community. Thanks to the richness in historical material and type specimens from various countries there was an active international loan correspondence. In the old museum archives we found that more than 350 specialists covering all groups received material on loan for scientific revision and enthusiastically learnt that historically important specimens were not lost, but easily available.

In the 1970s the scorpion collection was reorganized, some material that had dried out was discarded and a new inventory number (Sc. \#\#\#), referring to species lots, was used for the catalogue of the extant material. By 'species lots', we mean one or more specimens of the same species stored in the same vial or jar.

\section{Electronic database}

Since 1997 all the invertebrate collections have been recorded in an electronic database. Original label information was basically copied, except that country names were added or changed according to current usage and minor emendations were made for homogeneity of style. Unfortunately, old specimens often bear inadequate locality data. The extensive work of comparing the old manuscript catalogue data with electronic database is still in progress; moreover it does not yet contain all the information and systematic notes made by the specialists.

\section{Results}

We found numerous discrepancies when comparing the catalogues with the real status of the collections: e.g. number of specimens in each tube, registration numbers, state of conservation and notes about localities. A problem - common to several museum

collections - is keeping track of the high number of specimen loans all over the world, some of which were never returned or were seriously damaged during shipment.

\section{The scientific value of the scorpion collection}

The historical scorpion collection of the MZUT is quite large with more than 3,300 specimens divided into 777 lots comprising about 300 species, 67 genera, and 11 families from all continents, except Antarctica. The majority of the specimens are preserved in ethanol. We periodically undertake a survey of the collections, checking the conservation of the specimens. In general, the samples are in good condition and the original labels are mostly present, although locality data are often unclear or lacking.

The majority of the lots are from Africa (246) and South America (183); however Europe (120) and Asia (99) are also well represented. Less numerous are the samples from North America (52), Central America (50) and Oceania (11) (Fig. 1). Sixteen samples are without data. With regard to Africa, the states yielding the larger numbers of samples are South Africa (44), Libya (40), Eritrea (38), and Somalia (36). South America is well represented by Ecuador (45), Argentina (36) and Chile (24). Most of the North American samples come from Mexico (39) while with regard to Europe, the state with the 
maximum number of samples (91) is Italy.

The work of many specialists over a period of nearly 200 years, describing new species from all over the world, explains the remarkable number of types that makes the Turin Museum collections of great scientific significance. Type material can be attributed to 26 species or subspecies, comprising important samples studied by Borelli at the beginning of the 20th century (Tab. 1).

We also recently relocated the syntypes of Tityus argentinus Borelli, 1899 (Fig. 2a) - which was presumed for many years to be lost (cf. FET \& LOWE 2000) - the holotype of Uroplectes silvestrii Borelli, 1913 = Butheoloides silvestrii (Borelli, 1913) and the holotype of Hemiscorpius tellinii Borelli, 1904 (KOVAŘÍK \& MAZUCH 2011).

\section{Scientists and collectors}

The collection gained much significance thanks to the extensive scientific work of Alfredo Borelli (1858-1943). He collected new or important species, examined collections from all over the world for his systematic and taxonomic studies, including samples collected by famous scientists and travellers. His reputation as a scorpiologist was such, that many of the major specialists in 19th century arachnology were corresponding with him to seek advice, to exchange specimens and to send him copies of their own work for comments.

Borelli focused his attention on exotic fauna as well (BORELLI 1900) and explored South America (Argentina, Paraguay and Bolivia) in 1893-94 and in 1895-96 (BORELLI 1899a). He was an entomologist, zoologist and arachnologist: his large entomological collection and his sixty-seven papers on Dermaptera are well known (ZAVATTARI 1943). More than sixty of the scorpion labels bear Borelli's name, either as collector, donor, author or identifier. Borelli published 35 papers describing new species and identifying material from Italian and foreign countries. He was in touch with renowned specialists worldwide and the collection of the Turin museum increased thanks to exchanges and donations. Moreover, he collected vertebrates, especially during his South American expeditions.

An important zoologist who worked with Borelli was Enrico Festa (1868-1939), assistant at the MZUT and a naturalist who travelled extensively and collected in South America and the Mediterranean basin. Among the scorpions collected in Ecuador by Festa there are important type specimens, studied and determined by BORELLI (1899b). Moreover, he visited several localities in Libya: the Benghazi plain, Gheminez, Sidi-Chelan and Coefia. Rich material was collected by Festa in Palestine, Rhodes (BORELLI 1913a) and Italy. BORELLI (1924) studied the material from the expeditions of Enrico Festa and named some new species after him (for example Tityus festae Borelli, 1899 (Fig. 2b), Chactas festae Borelli, 1899 (Fig. 2c) and Ananteris festae Borelli, 1899).

Filippo Silvestri (1873-1949) was an Italian entomologist and professor in Portici (Naples). During his travels in Argentina, Paraguay and Bolivia (1893-1896) he collected several specimens. From the 1912-1913 expedition in Olokemeji and Lagos (Nigeria) he sent more than 30 lots of scorpions to the Turin museum (BORELLI 1913b); one of which is Uroplectes silvestrii Borelli, 1913. BORELLI (1901a) described the specimens collected by Silvestri, providing an important contribution to the knowledge of scorpion fauna from South America and, in particular, of the till then poorly-known Argentinean scorpions. Among the scorpions collected there are important type specimens such as Tityus uruguayensis Borelli, 1901 (Fig. 2d) and Tityus mattogrossensis Borelli, 1901 (Fig. 2e).

The following scientists also contributed to the scorpion collection in Turin and merit being briefly noted. Aleksei Birula (1864-1937), director of St. Petersburg Zoological Museum, was the author of the first book on Russian scorpions (BIRULA 1917). Birula donated and determined Turin specimens from Turkmenistan, Pakistan, Uzbekistan, Armenia, Iran, Azerbaijan and China.

The German naturalist Karl Kraepelin (18481915), was a specialist in the study of scorpions, centipedes, spiders and solpugids. He compared several of Borelli's scorpions with specimens in the 'Naturhistorisches Museum Hamburg' (BORELLI 1899b, 1901a). Numerous species were named in his honour e.g. Iurus kraepelini von Ubisch, 1922 and Tityus kraepelini Borelli, 1899 (a synonym of Tityus pugilator Pocock, 1898).

Reginald Innes Pocock (1863-1947) was a British zoologist and assistant at the British Museum of Natural History. POCOCK (1901) compared several specimens, sent by Borelli, with the type specimens in the London museum. Several important species from India and Africa were sent to him for determination. Adolfo Ducke (1876-1959) was an entomological technician (OBREcht \& Huber 1993) in the Pará Museum (Brazil). Ducke and Francisco Diaz da 

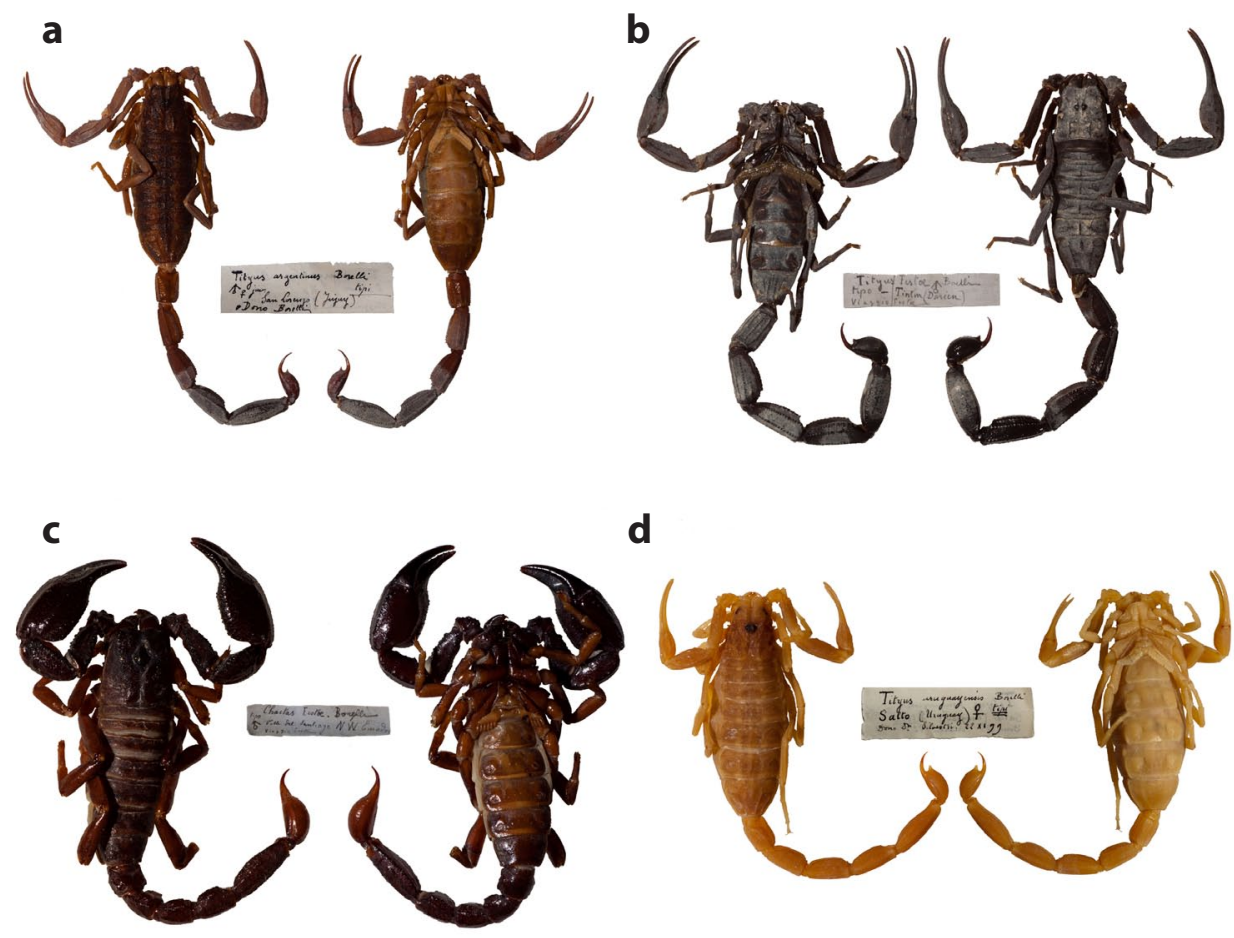

d
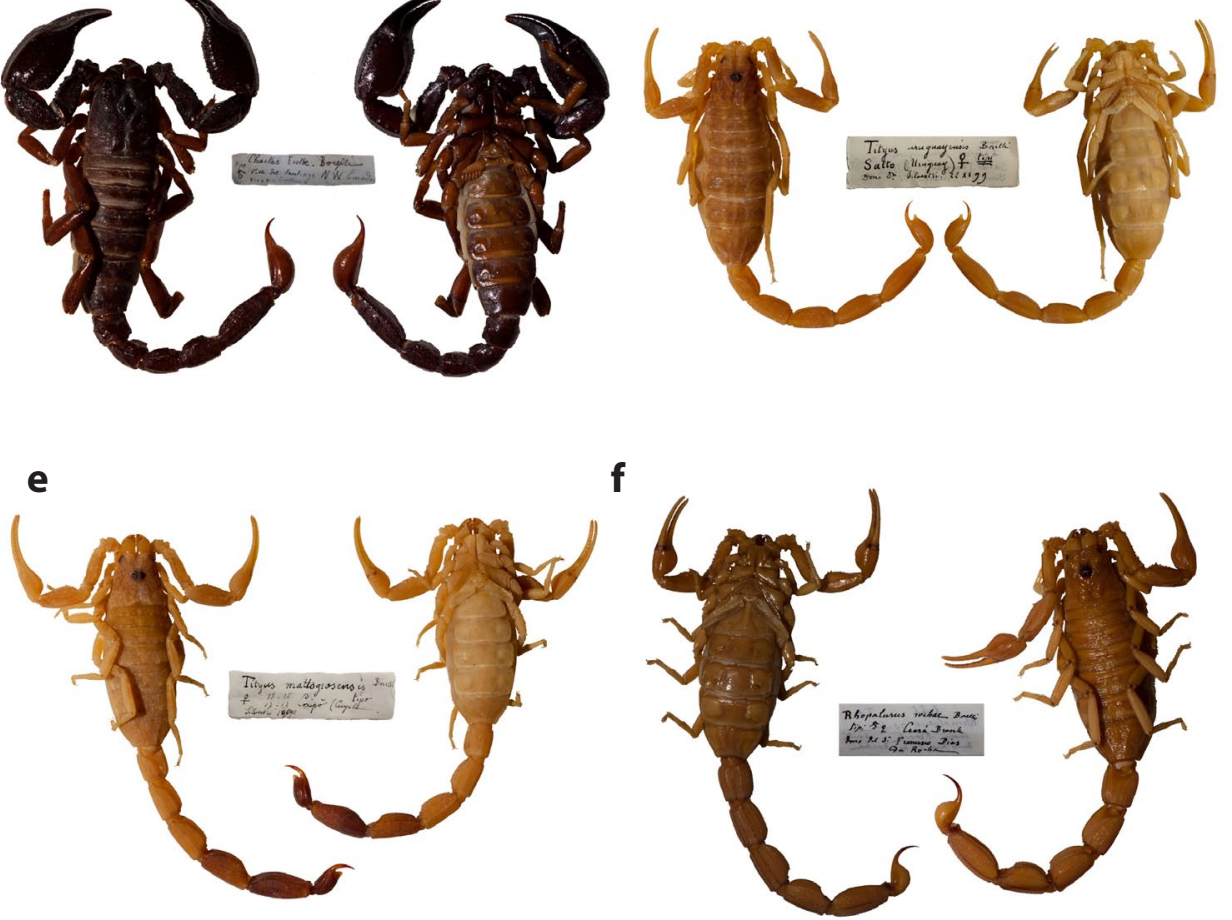

Fig. 2: Type specimens of the MZUT scorpion collection: a. Tityus argentinus Borelli, 1899; b. Chactas festae Borelli, 1899; c. Tityus festae Borelli, 1899; d. Tityus mattogrossensis Borelli, 1901; e. Tityus uruguayensis Borelli, 1901;

f. Rhopalurus rochae Borelli, 1910.

Rocha from Rocha Museum sent several Brazilian specimens to Borelli. Among them BORELLI (1910) discovered two new species, Tityus duckei Borelli, 1910 (a synonym of Tityus silvestris Pocock, 1897) and Rhopalurus rochae Borelli, 1910 (Fig. 2f).

Paolo Magretti (1854-1913), a specialist on ants, collected in eastern Sudan and Eritrea (SORDELLI 1914). All of his scorpion samples - described by BORELLI (1901b) - were collected in the surroundings of Keren (Eritrea) in 1883.
Many specimens collected in the surroundings of Cape Town, South Africa, were sent by William Frederick Purcell (1866-1919), a South African arachnologist. He became First Assistant in the South African Museum in 1896. Retiring in 1905, he spent the rest of his life collecting arachnids and insects (IZIKO SOUTH AFRICAN MusEum 2011).

About 25 lots came from Costa Rica as a gift of Paul (Paolo) Biolley (1862-1908), naturalist of the 'Museo Nacional in San Jose'. He studied the local invertebrate fauna; increasing the general knowledge 


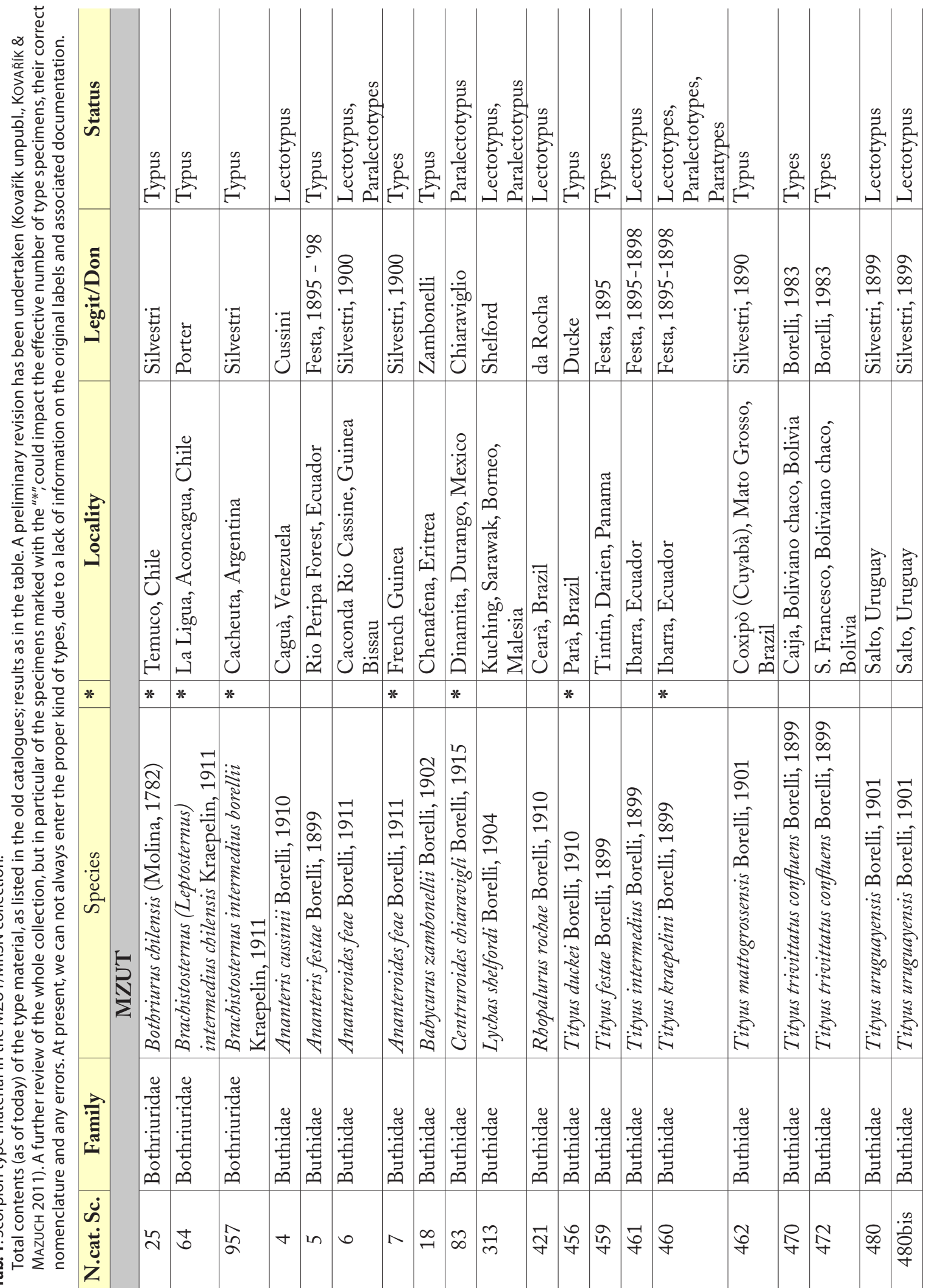




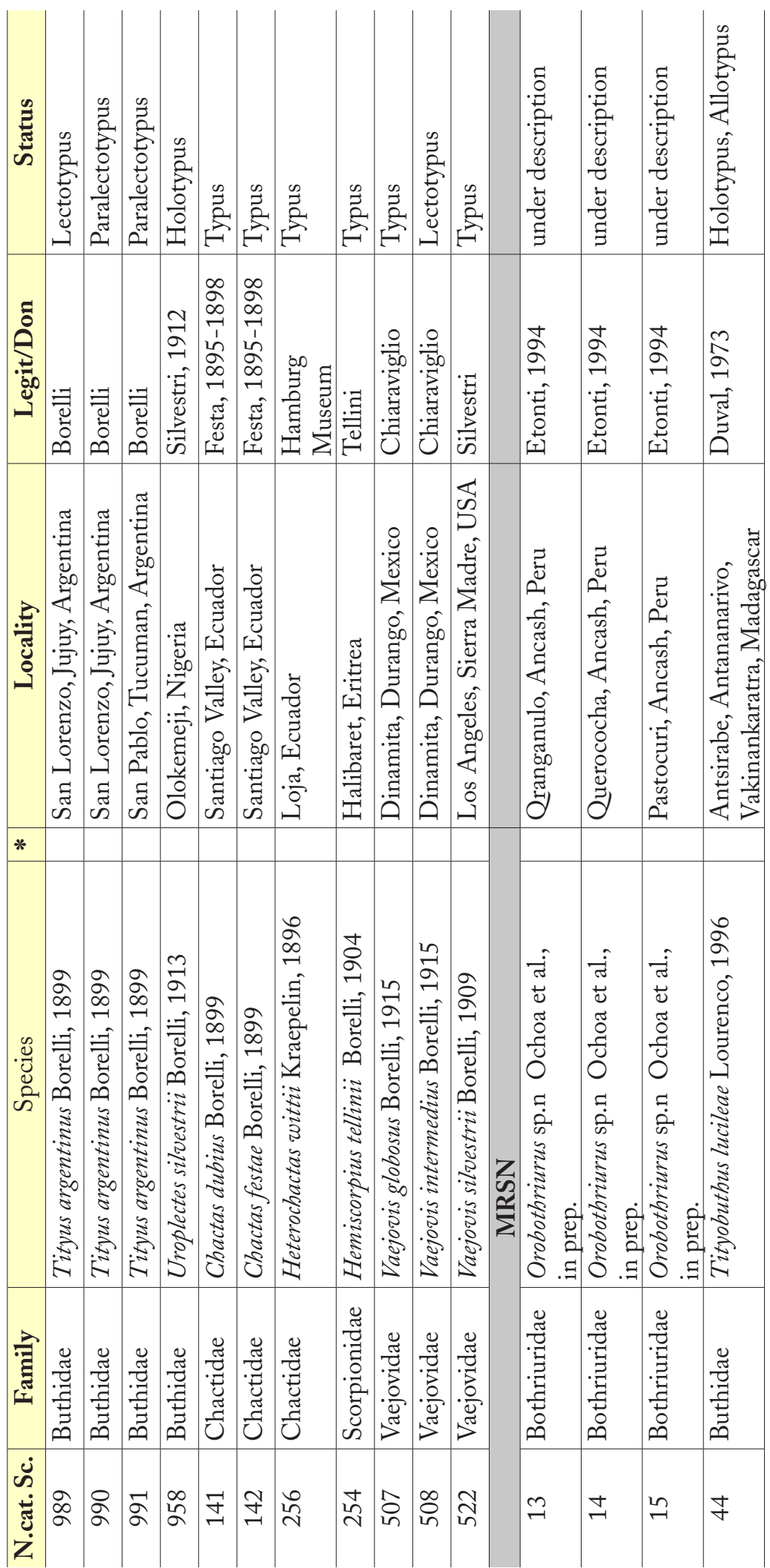

about Costa Rica, and in particular the western coast of Cocos Island (COGNETTI DE MARTIIS 1908).

The Museo Regionale di Scienze Naturali (MRSN), Collection

The most recent scorpion acquisitions in the 'Museo Regionale di Scienze Naturali' (MRSN) as of today consist of 122 specimens, 59 tubes and 27 species belonging to 16 genera and 6 families. Except for the Italian and Greek specimens of the genus Euscorpius, the other specimens are mainly from South America (collected by C. Bordon, M. Etonti and J. Cei ) and Africa, in particular Madagascar (collected by F. Andreone and C. Duval). Two type species are present: Tityobuthus lucileae Lourenço, 1996 and Orobotbriurus sp. n., the latter currently being described by José A. Ochoa and colleagues.

\section{Conclusions}

The 'Museo Regionale di Scienze Naturali' of Turin, heir to the prestigious Zoological Museum of Turin University, maintains the important role of ensuring the conservation and availability of these collections. The scorpion collection needs to be revised and the nomenclature must be updated in order to obtain the correct number of species and specimens. Large amounts of the material have already been identified, although there are still some jars to be sorted and examined; among them a rich collection made by the entomologists C. Bordon (Venezuela) and M. Etonti (Greece, Turkey, Peru, Chile). This work will proceed so long as the funding and human resources are available. 


\section{References}

BIRULA A.A. (1917): Fauna Rossii I sopredel'nykh stran preimushchestvenno po kollektsiyam Zoologicheskogo muzeya Imperatorskoi [since 1917 - Rossiiskoi]. Akademii Nauk. Arachnoidea, Scorpions 1 (1): 1-224

BORELLI A. (1899a): Scorpioni Buthidae: viaggio del dott. A. Borelli nella Repubblica Argentina e nel Paraguay (23). - Bollettino dei Musei di zoologia ed anatomia comparata della Regia Università di Torino 14 (336): 1-6

Borelli A. (1899b): Scorpioni: viaggio del dott. Enrico Festa nell'Ecuador e regioni vicine. - Bollettino dei Musei di zoologia ed anatomia comparata della Regia Università di Torino 14 (345): 1-18

Borelli A. (1900): Di alcuni scorpioni del Chile. - Revista Chilena de Historia Natural 5: 61-66

Borelli A. (1901a): Scorpioni raccolti dal Dott. Filippo Silvestri nella Repubblica Argentina e regioni vicine. Bollettino dei Musei di zoologia ed anatomia comparata della Regia Università di Torino 16 (403): 1-12

BORELLI A. (1901b). Scorpioni Buthidae: Materiali per la conoscenza della fauna Eritrea raccolti dal Dott. Paolo Magretti. Scorpioni. - Bollettino dei Musei di zoologia ed anatomia comparata della Regia Università di Torino 16 (384): $1-5$

BorELLI A. (1910): Scorpioni nuovi o poco noti del Brasile. - Bollettino dei Musei di zoologia ed anatomia comparata della Regia Università di Torino 25 (629): 1-8

BORELLI A. (1913a): Escursioni zoologiche del Dr. Enrico Festa nell'Isola di Rodi. - Bollettino dei Musei di zoologia ed anatomia comparata della Regia Università di Torino 28 (675): 1-3

BORELLI A. (1913b): Scorpioni raccolti dal prof. F. Silvestri nell'Africa occidentale. - Bollettino del Laboratorio di zoologia generale e agraria della Regia Scuola superiore d'agricoltura in Portici 7: 219-220
BorELLI A. (1924): Missione zoologica del Dr. E. Festa in Cirenaica. XVI. Scorpioni e Solifughi. - Bollettino del Museo di Zoologia e Anatomia Comparata della Regia Università di Torino 39 (26): 1-16

CognetTi De MARTIIS L. (1908): Paolo Biolley: Necrologia. - Bollettino del Museo di Zoologia e Anatomia Comparata della Regia Università di Torino 28 (589): 1-2

FET V. \& G. LOWE (2000): Family Buthidae C. L. Koch, 1837. Pp. 54-286. In: FET V., W.D. SISSOM, G. LOWE \&M.E. BRAUNWALDER (eds.): Catalog of the scorpions of the world (1758-1998). The New York Entomological Society, New York. 689 pp.

KOVAŘíK F. \& T. MAZUCH (2011): Hemiscorpius novaki sp. n. from Somaliland (Scorpiones: Hemiscorpiidae). - Euscorpius 126: 1-9

IZIKo South African Museum (2011): W. F. Purcell. In: History of Koopmans de Wet House. - Internet: http://www.iziko.org.za/static/page/history-of-koopmans-de-wet-house\#purcell

OBRECHT E. \& C. HubER (1993): Ducke type specimens and other Brazilian insect types in the Emil A. Goeldi collection in the Natural History Museum Bern (Switzerland). An annotated catalogue. - Jahrbuch des Naturhistorischen Museums Bern 11: 163-184

Pocock R.I. (1901): On a new species of the genus Parabuthus. - Bollettino dei Musei di Zoologia dell'Università di Torino 16 (382): 1

TORTONESE E. (1957): Venticinque anni di vita del Museo Zoologico di Torino (1930-1955). - Natura, Milano. 27pp.

ZAVATTARi E. (1943): Alfredo Borelli. - Memorie della Società Entomologica Italiana 22: 125-133 